\title{
Microsatellite Analysis of Genetic Diversity and Structure of Farmer Selected Genotypes of Tree Bean (Parkia timoriana (DC.) Merr) in Manipur
}

\author{
C.S. Phurailatpam, N. Lyngdoh ${ }^{1 *}$, Manokar Jaganathan ${ }^{2}$, Pavan Kumar Thunga ${ }^{2}$, \\ Poorna Bhat ${ }^{2}$ and G. Ravikanth ${ }^{2}$ \\ Department of Tree Improvement, College of Horticulture and Forestry, Central Agricultural University \\ Pasighat-791 102, India; ${ }^{1}$ Biodiversity Research Centre, Mizoram University, Tanhril, Aizawl-796 004, India \\ ${ }^{2}$ ATREE, Royal Enclave, Sriramapura, Jakkur Post, Bangalore 560 064, India \\ E-mail: lyngdoh@gmail.com
}

\begin{abstract}
$\overline{\text { Abstract: Microsatellite markers were used to analysed the genetic diveristy and structure of twenty six farmer-selected trees in the valley }}$ districts of Manipur, India. Three markers, which displayed high polymoprhic information content (88.9\%) and allelic richness ranging between 14 and 16. The number of allele per locus $(\mathrm{Na})$ in the pooled selected population was 5.33 , number of private alleles was 0.66 and Shannon Diversity Index (I) was 1.12, indicating high diversity values. Population wise, highest values were obtained in Imphal West ( $\mathrm{Na}=3.67$; number of private alleles $=1.33, \mathrm{I}=1.05)$ and lowest in Chandel $(\mathrm{Na}=1.67$; number of private alleles $=0, \mathrm{I}=0.24)$. Analysis of molecular variance indicated much of variability resided within selections $(49.5 \%)$ and very less among groups (12.5\%). Structure analysis revealed that selections have originated from two genepools, but with no clear-cut inclination of any selection to either genepool. The results indicate that ample genetic variation existed in the twenty farmer-selected trees and informal selections by farmers do not display any genetic deficiencies. However there is a need for an extensive genetic survey comprising of natural and planted populations across the state to enable more meaningful comparisons.
\end{abstract}

Keywords: Domestication, Genetic bottleneck, SSR, Shannon Diversity Index, Yongchak

Indigenous fruit tree species (IFTs) are trees with edible fruits, which naturally grow within a specific geographic location and are often characterized by limited development relative to their potential (Mabhaudhi et al 2017). Throughout the tropics, there are many IFTs that supplement nutritional demands and support family income of rural communities (Reed 2017, Ickowitz et al 2014, Vira et al 2015). Some of the IFTs have even surpassed local usage and are presently in high demand triggering widespread domestication (Mithofer 2005, Sankanur et al 2017) and introduction in farmer's fields. The maintenance of adequate amounts of genetic variation in the domesticated population is essential to allow for continued genetic gains over multiple generations (Johnson et al 2001). This is especially relevant for IFTs where the formal production system of propagation material in most species is still lacking and farmers generally use planting materials from random, unknown and often genetically narrow sources. Conflicting evidence has emerged on the level of genetic diversity harboured by planted populations across the globe. For example, microsatellite markers showed clear genetic differences between matched natural and planted populations of Inga edulis, an indigenous fruit of the Amazon, raising doubts over the sustainability of planted populations (Hollingsworth et al
2005). On the contrary, similar studies on Meru oak (Vitex fischeri) using RAPD (Lengleek et al 2006) and sheanut (Vitelleria paradoxa) using microsatellite markers (Kelly et al 2004) found little difference in diversity levels between agroforestry trees and the natural population stand. With natural habitats and useful resources fast depleting due to land use changes and high extraction pressure, planted populations may become sole repositories of genetic diversity for many IFTs in the near future. Further, since many of the planted populations will be the founding population for on and off farm plantation, ascertaining the level of variation and genetic structure becomes essential.

Parkia timoriana (DC.) Merr. [Syn. Parkia roxburghii G. Don.] is a tree that yields a fruit (henceforth referred to a pod), which is used for many culinary purposes in the North east region of India. It is commonly called Tree Bean and naturally distributed in North East India and South East Asia including Bangladesh, Burma (Myanmar), Thailand and the Malaysian region. The pods have high market value prized between $65 \$$ to $90 \$$ for 100 pods during its peak season (Roy et al 2016). Aside from the pods being a source of food, it is nutritional (Longvah and Deosthale 1998, Salam et al 2009), has many medicinal uses and diverse bioactivity (Angami et al 2017). In the state of Manipur Tree bean is locally known as 
"Yongchak" and commonly consumed as a vegetable, salad or 'chutney'. It is extensively planted in village areas, along roadsides, home gardens and agricultural lands. Based on palatability and morphological traits, traditional cultivars of tree beans have been identified (Anon 1981, Meitei and Singh 1990).

In a larger exercise aimed to initiate a domestication program of Tree Bean in Manipur, we identified farmerselected trees in the valley districts of Manipur, India. These farmer selections were best in their respective sites for pod quality and/or pod production and the preferred choice as mother trees for propagation. Using SSR markers we assessed the genetic diversity and structure of these selected individuals to ascertain whether selection by farmers has invariably resulted in genetic deficiencies in the population. Such investigations are especially crucial in domestication programs that are in participatory mode to refine the selection procedure of good genotypes.

\section{MATERIAL AND METHODS}

The study was conducted during 2017-19 and samples were collected from the valley districts of Manipur. We randomly selected sites in six districts of the state and at each site we enquired village elders about the best tree bean trees in their area in terms of eating quality, pod characteristics and production and from where they preferred to obtain seeds for propagation. Based on consensus at each site, we located the farmer-selected trees and geo referenced their location. A total of 26 trees were located in this manner from six districts of the state (Table 1).

Leaf samples from the 26 adult trees were collected, dried in silica gel and stored at $-20^{\circ} \mathrm{C}$. The genomic DNA was extracted from the leaf samples $(200 \mathrm{mg})$ using the cetyltrimethylammonium bromide protocol (Doyle and Doyle 1987) with relevant modifications. The extraction buffer consisted of $100 \mathrm{mMTris}$, 20mm EDTA (ethylene diamine tetra acetic acid), $1.4 \mathrm{M} \mathrm{NaCl}$ and $2 \%$ CTAB. The extracted DNA were treated with $4 \mathrm{ul}$ of $50 \mathrm{mg} / \mathrm{ul}$ RNAse and kept at $37^{\circ} \mathrm{C}$ for 30 mins. The presence of the DNA was confirmed through electrophoresis in ethidium-bromide stained $0.8 \%$ agarose gels. The DNA was quantified using a spectrophotometer at absorbance $\mathrm{A} 260 \mathrm{~nm} / \mathrm{A} 280 \mathrm{~nm}$. All the 26 samples were diluted in TE buffer to a final concentration of $50 \mathrm{ng} / \mu \mathrm{l}$ and stored at $-20^{\circ} \mathrm{C}$ before amplification.

The diluted DNA (50 $\mathrm{ng}$ ) were subjected to polymerase chain reaction (PCR) using shortlisted three nucleotide microsatellite primer pairs from $P$. panurensis (Leuttmann et al 2010); P. bigobulosa (Lassen et al 2014) (Table 2). The PCR amplification was carried out in $20 \mu \mathrm{L}$ reaction containing 2.0 $\mu \mathrm{L}$ template DNA (30-50ng/ml), 2.5 $\mu \mathrm{L} 10 \times$ PCR buffer, $2.5 \mathrm{ml}$ of $2.5 \mathrm{mM}$ dNTP, $1.0 \mu \mathrm{L}$ of forward and reverse primer each, $0.2 \mu \mathrm{L}$ of $3 \mathrm{U}$ Taq polymerase and the final volume was made up to $20 \mu \mathrm{L}$ with nuclease free sterile water. An master cycler gradient (Eppendorf) was used with following conditions: Initial denaturation at $94^{\circ} \mathrm{C}$ for 4 min followed by 38 cycles of $94^{\circ} \mathrm{C}$ for $1 \mathrm{~min}, 46-58^{\circ} \mathrm{C}$ (primer specific annealing temperature) for $35 \mathrm{sec}$, and elongation at $72^{\circ} \mathrm{C}$ for $1 \mathrm{~min}$ and final extension at $72^{\circ} \mathrm{C}$ for $10 \mathrm{~min}$. Amplified products were genotyped using ABI PRISM3130 genetic analyser (Applied Biosystems, Chromous Biotech Bangalore, India). The electropherograms were manually checked for specific artefact peaks, split peaks before scoring the alleles using Genemarker Ver 3.0.1 (www.softgenetics.com).

Genetic diversity measures were analysed at three level; individual, geographical and pooled level. The observed number of alleles, effective number of alleles, private alleles, observed and expected heterozygosity and Shannon's diversity index analysis were carried out using POPGENE $V$ 1.31 and GenAIEx 6.502 softwares (Yeh and Boyle 1997, Peakall and Smouse 2012). Based on the tree's geographical origin, the individuals were grouped into six populations namely Imphal West, Kanpokpi, Bishnupur, Churachandpur, Kamjong and Chandel. Analysis of molecular variance (AMOVA) was also carried out to assess the genetic variance among the groups, individual trees as well as within each tree. A model-based program, STRUCTURE (Pritchard et al 2000), was used to determine the genetic relationship among the 6 populations of $P$. timoriana. In this method, fractional membership of each individual was assigned to a specific cluster (K). The program was performed under the assumptions of admixture and no admixture model with the allele frequencies correlated. The program was performed with $5,00,000$ burning period with 20,00,000 MCMC runs assuming $\mathrm{K}=1$ to $\mathrm{K}=8$ for both the models. Ten replicates were run for each $\mathrm{K}$ for robust results in achieving the best possible $K$ value. To identify the best $K$, Evanno's $\Delta K$ method was used in the STRUCTURE HARVESTER (Dent and VonHoldt 2012). To identify that the replicate runs were consistent and also to modify labels and colours, CLUMPAK Ver1.1 was used (Kopelman et al 2015). Principal Component Analysis (PCA) was performed to identify clusters using GENODIVE Ver 3.0 (Meirmans 2020) and plotted using Origin prob 2020 (Origin lab corp). All the files were converted using CONVERT Ver 1.3.1 (Glaubitz 2004).

\section{RESULTS AND DISCUSSION}

Three microsatellite or simple sequence repeat (SSR) markers were used to estimate the genetic diversity and structure of 26 farmer-selected trees from Manipur. The number of alleles detected was 45 and the number of alleles 
ranged from 14 to 16 . The average value of polymorphic information content (PIC) for three primers was $88.9 \%$, the highest being in locus PBL 21 and lowest PP9. The markers used in the study showed higher allelic richness as compared to 5 SSR markers used in Parkia biglobosa, which detected a total of 55 alleles ranging between 10 and 14 (Popoola et al 2020).
The diversity indices estimated for twenty six genotypes are shown in Table 3. The number of alleles per locus $(\mathrm{Na})$ varied from 1.00 in 11 individuals to 1.66 in 3 individuals, with a mean of 1.30 (Table 3 ). The observed heterozygosity $\left(H_{0}\right)$ ranges from 0 in 11 individuals to 1 in Tree No. 2 from Imphal West which also reported the highest Shannon diversity index (0.69). The zero values obtained for observed

Table 1. Details of location and GPS coordinates of 26 farmer-selected genotypes of tree bean (Parkia timoriana) from Manipur

\begin{tabular}{|c|c|c|c|c|c|}
\hline \multirow[t]{2}{*}{ Tree no. } & \multirow[t]{2}{*}{ Village } & \multirow[t]{2}{*}{ District } & \multicolumn{3}{|c|}{ GPS Coordinates } \\
\hline & & & Longitude & Latitude & Elevation (m) \\
\hline T1 & New Keithelmanbi & Imphal-West & $\mathrm{N} 24^{\circ} 46^{\prime} 19.38^{\prime \prime}$ & $\mathrm{E} 93^{\circ} 47^{\prime} 43.49^{\prime \prime}$ & 802 \\
\hline T2 & Laimanai, Langol & Imphal-West & $\mathrm{N} 24^{\circ} 50^{\prime} 23.5^{\prime \prime}$ & $\mathrm{E} 93^{\circ} 55^{\prime} 07.6$ & 781 \\
\hline T3 & Oinam Leikai, Pishum & Imphal West & N24ㄴ6'59.7' & E93 $55^{\prime} 58.8^{\prime \prime}$ & 804 \\
\hline T4 & M S Leirak, Yaiskul & Imphal-West & N244' $31.4^{\prime \prime}$ & E93 $56^{\prime} 14.0^{\prime \prime}$ & 786 \\
\hline T5 & Kanglatombi, Ward 1 & Imphal-West & 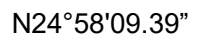 & E935'ㅅ․ & 854 \\
\hline T6 & Kanglatombi, Ward 1 & Imphal-West & N24도' $9.84^{\prime \prime}$ & E935'16.73" & 854 \\
\hline $\mathrm{T7}$ & Kholep Village & Kangpokpi & $\mathrm{N} 25^{\circ} 01^{\prime} 03.95^{\prime \prime}$ & E935'ㄴ.96" & 982 \\
\hline T8 & Saitu & Kangpokpi & N2501'57.3" & E9354'25.3” & 1192 \\
\hline T9 & Keithelmanbi, & Kangpokpi & N2506'1.43" & E9356'53.72" & 980 \\
\hline T10 & Keithelmanbi & Kangpokpi & N2506'14.0" & E9357'01.3" & 980 \\
\hline T11 & Ward 8 & Bishnupur, & N24ㅇ' $37^{\prime} 38.65^{\prime \prime}$ & E934ㄴ'47.6” & 802 \\
\hline T12 & Ward 8 & Bishnupur, & N24 $37^{\prime} 25.01^{\prime \prime}$ & E93 $45^{\circ} 44.73^{\prime \prime}$ & 802 \\
\hline T13 & Ward 8 & Bishnupur, & N243' $24.85^{\prime \prime}$ & 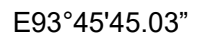 & 802 \\
\hline T14 & Moirang & Bishnupur & N24웅' $20.4^{\prime \prime}$ & E93²45'39.6” & 762 \\
\hline T15 & Zenhang Lenka & Churchandpur & $\mathrm{N} 24^{\circ} 20^{\prime} 48.5^{\prime \prime}$ & E9342'07.8” & 807 \\
\hline T16 & Zenhang Lenka & Churchandpur & 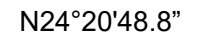 & E93²42'08.4" & 816 \\
\hline T17 & Rengkai Road & Churchandpur & $\mathrm{N} 24^{\circ} 20^{\prime} 43.01^{\prime \prime}$ & E9341'59.27"' & 830 \\
\hline T18 & Elim Veng & Churchandpur & 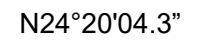 & E934ㄴ'47.2" & 854 \\
\hline T19 & Sampui & Kamjong & N24ํ5'07.1" & E94⒉ 29'10.3" & 1303 \\
\hline T20 & Sampui & Kamjong & 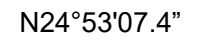 & E94²9'11.2" & 1306 \\
\hline T21 & Sampui & Kamjong & N24ํ5'06.4" & E94 $29^{\prime} 10.2^{\prime \prime}$ & 1312 \\
\hline T22 & Sampui & Kamjong & N24ํ5'․ $6.47^{\prime \prime}$ & E94²9'9.41" & 1307 \\
\hline T23 & Christian Village & Chandel & N2418'58.80" & E9359'3.90" & 880 \\
\hline T24 & Christian Village & Chandel & N24ํ19'00.8" & E9359'01.6" & 880 \\
\hline T25 & Liwa Khulen & Chandel & N24ㅇ'ㄹ'19.60" & $\mathrm{E} 94^{\circ} 0^{\prime} 40.10^{\prime \prime}$ & 830 \\
\hline T26 & Liwa Khulen & Chandel & N24을'20.91" & E94우 $0^{\prime} 39.45^{\prime \prime}$ & 831 \\
\hline
\end{tabular}

Table 2. Details of nuclear SSR markers used for genetic analysis of natural, planted and selected populations of tree bean (Parkia timoriana) from Manipur

\begin{tabular}{|c|c|c|c|c|}
\hline Locus & Primer sequence along with the labeled marker & $\mathrm{Ta}\left({ }^{\circ} \mathrm{C}\right)$ & Repeat motif & Size range (bp) \\
\hline PP9 & $\begin{array}{l}\text { VIC-F: GGGGCTTGTGTCTCTCACTG } \\
\text { R: ACTTTGAAGGCACGAGATGG }\end{array}$ & 58 & $(\mathrm{AC}) 8$ & $204-262$ \\
\hline PBL21 & $\begin{array}{l}\text { FAM-F: TGTTGCTTTTGCTTTTGCTG } \\
\text { R: CCCTCTGCAGAATTGAGTCC }\end{array}$ & 58 & $(\mathrm{CA}) 21$ & $250-290$ \\
\hline PRO1 & $\begin{array}{l}\text { VIC-F: ACTCCTGCCTTACCACATCC } \\
\text { R: TAGCAGCCTATCGACCGC }\end{array}$ & 46 & $(A C) 8$ & $270-310$ \\
\hline
\end{tabular}

Note: Ta- Annealing temperature, bp - base pair length 
heterozygosity and Shannon diversity index in 11 individuals is due to their homozygous condition at all three loci; hence genetically undifferentiated in terms of heterozygosity levels based on the primers used. However, when the individuals were analyzed as a population, $\mathrm{Na}$ was 5.33 , number of private alleles was 0.66 and Shannon Diversity Index was 1.12. These reported diversity values were higher than those reported for species of the same genera by Jacob et al (2019) for 19 landraces of Parkia biglobosa from Nigeria using five SSR primers (0.49) and Parkia speciosa (0.96) from Malaysia using RAPD markers (Lee et al 2002). The three microsatellite markers used in the study were also able to detect larger variation as compared to 19 ISSR markers used by Thangjam (2014) for 3 populations of the same species from Manipur where the highest Shannon index was 0.19 and number of alleles 1.33. Based on only three primers, we are able to detect larger variation in the selected population and genetic diversity values momentarily indicate the absence of any genetic bottleneck event during the selection process by farmers. Tree bean is commercially propagated by seeds since there are no vegetative propagation protocols developed, and this could be one of the reasons why high genetic diversity is maintained within the selected population. However, pooled genetic variation of tree bean in the state needs to be ascertained by sampling natural as well as planted populations, which can be used as a reference point for more meaningful comparison.

The 26 selections were further divided into 6 groups based on geographical origin of the tree and genetic parameters for all groups are shown in Table 4. The number of alleles $(\mathrm{Na})$ ranged from 1.67 in Chandel to 3.67 in Imphal west, which also showed the highest number of private

Table 3. Summary statistics addressing genetic diversity of 26 farmer-selected genotypes of Tree Bean (Parkia timoriana)

\begin{tabular}{|c|c|c|c|c|c|c|c|}
\hline Tree No. & $\mathrm{Na}$ & $\mathrm{Ne}$ & $\mathrm{I}$ & $\mathrm{Ho}$ & $\mathrm{He}$ & Obs_Hom & Exp_Hom \\
\hline $\mathrm{T} 1$ & 1.00 & 1.00 & 0.00 & 0.00 & 0.00 & 1.00 & 1.00 \\
\hline $\mathrm{T} 2$ & 2.00 & 2.00 & 0.69 & 1.00 & 1.00 & 0.00 & 0.00 \\
\hline T3 & 1.00 & 1.00 & 0.00 & 0.00 & 0.00 & 1.00 & 1.00 \\
\hline $\mathrm{T} 4$ & 1.66 & 1.66 & 0.46 & 0.66 & 0.66 & 0.33 & 0.33 \\
\hline $\mathrm{T} 5$ & 1.33 & 1.33 & 0.23 & 0.33 & 0.33 & 0.66 & 0.66 \\
\hline T6 & 1.00 & 1.00 & 0.00 & 0.00 & 0.00 & 1.00 & 1.00 \\
\hline $\mathrm{T7}$ & 1.66 & 1.66 & 0.46 & 0.66 & 0.66 & 0.33 & 0.33 \\
\hline T8 & 1.33 & 1.33 & 0.23 & 0.33 & 0.33 & 0.66 & 0.66 \\
\hline T9 & 1.33 & 1.33 & 0.23 & 0.33 & 0.33 & 0.66 & 0.66 \\
\hline T10 & 1.00 & 1.00 & 0.00 & 0.00 & 0.00 & 1.00 & 1.00 \\
\hline $\mathrm{T} 11$ & 1.00 & 1.00 & 0.00 & 0.00 & 0.00 & 1.00 & 1.00 \\
\hline T12 & 1.00 & 1.00 & 0.00 & 0.00 & 0.00 & 1.00 & 1.00 \\
\hline T13 & 1.33 & 1.33 & 0.23 & 0.33 & 0.33 & 0.66 & 0.66 \\
\hline T14 & 1.33 & 1.33 & 0.23 & 0.33 & 0.33 & 0.66 & 0.66 \\
\hline T15 & 1.33 & 1.33 & 0.23 & 0.33 & 0.33 & 0.66 & 0.66 \\
\hline T16 & 1.66 & 1.66 & 0.46 & 0.66 & 0.66 & 0.33 & 0.33 \\
\hline T17 & 1.50 & 1.50 & 0.34 & 0.50 & 0.50 & 0.50 & 0.50 \\
\hline T18 & 1.00 & 1.00 & 0.00 & 0.00 & 0.00 & 1.00 & 1.00 \\
\hline T19 & 1.66 & 1.66 & 0.46 & 0.66 & 0.66 & 0.33 & 0.33 \\
\hline T20 & 1.33 & 1.33 & 0.23 & 0.33 & 0.33 & 0.66 & 0.66 \\
\hline $\mathrm{T} 21$ & 1.33 & 1.33 & 0.23 & 0.33 & 0.33 & 0.66 & 0.66 \\
\hline T22 & 1.00 & 1.00 & 0.00 & 0.00 & 0.00 & 1.00 & 1.00 \\
\hline T23 & 1.00 & 1.00 & 0.00 & 0.00 & 0.00 & 1.00 & 1.00 \\
\hline T24 & 1.50 & 1.50 & 0.34 & 0.50 & 0.50 & 0.50 & 0.50 \\
\hline T25 & 1.00 & 1.00 & 0.00 & 0.00 & 0.00 & 1.00 & 1.00 \\
\hline T26 & 1.50 & 1.50 & 0.34 & 0.50 & 0.50 & 0.50 & 0.50 \\
\hline
\end{tabular}

$\mathrm{Na}=$ No. of alleles; $\mathrm{Ne}=$ Effective No. of alleles; $I=$ Shannon's Index; Ho = Observed Heterozygosity; He = Expected Heterozygosity; Obs_Hom = Observed Homozygosity; Exp_Hom = Expected Homozygosity 
alleles (1.33), Shannon Diversity Index $(I=1.05)$ and expected heterozygosity $(\mathrm{He}=0.63)$. The genetic diversity parameter values were lowest from Chandel $(I=0.24$; $\mathrm{He}=0.13$ ), while populations from Kangpokpi and Bishnupur were similar in their diversity values. Earlier Thangjam (2014) had estimated genetic variation of 10 individuals each from Kangpokpi and Narankonjin (Imphal West) using ISSR markers and reported allelic richness of 1.32 and 1.18 and Shannon index of 0.19 and 0.11 , respectively, which were lower than values reported in our study (Table 4). This reenforces the strength of SSR markers to detect higher rate of polymorphism and high extent of allelic diversity and therefore are excellent molecular markers in studies of germplasm characterization, genetic diversity, and genetic mapping (Powell et al 1996).

Analysis of molecular variance (AMOVA) was performed to partition the genetic variance levels among groups, among selections, and within selection (Table 5). AMOVA results showed that much of variability resided within selections (49.5\%, Table 5). Significant difference among individuals ( $P$ $<0.01$ ) was observed, which represented $38 \%$ of the total variation, whereas the variability among groups accounted for $12.5 \%$. Low genetic differentiation between populations is a common feature among perennials (Hamrick et al 1979, Nevo et al 1984, Loveless and Hamrick 1984) primarily due to their outcrossing nature and high gene flow events (Hamrick and Godt 1996). These features are more relevant to Tree bean, which is an obligate outcrossing species since it is selfincompatible and pollinated by a bat species Eonycteris spelaea (Bumrungsri et al 2008), which has distance foraging flights up to $38 \mathrm{~km}$ (Start and Marshall 1976) promoting pollen dispersal over a large area. The lack of distinct population structure among genotypes is also demonstrated in the structure analysis. According to Evanno et al (2005), the maximum $\mathrm{K}$ represents the optimal number of clusters and $\mathrm{K}$

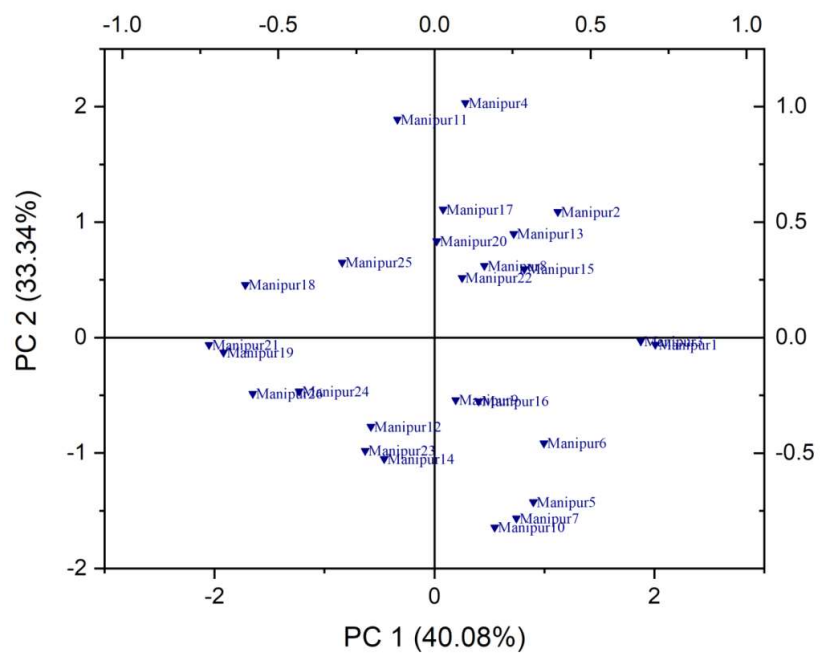

Fig. 2. Principal component analysis (PCA) for 26 farmerselected tree bean (Parkia timoriana) genotypes from Manipur

Table 4. Summary statistics addressing genetic diversity 26 farmer-selected genotypes of tree bean (Parkia timoriana) from Manipur grouped under 6 populations based on tree origin

\begin{tabular}{llllllll}
\hline Population & $\mathrm{N}$ & $\mathrm{Na}$ & $\mathrm{Ne}$ & $\mathrm{PA}$ & $\mathrm{I}$ & $\mathrm{Ho}$ & $\mathrm{He}$ \\
\hline Imphal West & 6 & 3.66 & 2.60 & 1.33 & 1.05 & 0.33 & 0.63 \\
Kangpokpi & 4 & 2.67 & 2.08 & 0.33 & 0.83 & 0.33 & 0.59 \\
Bishnipur & 4 & 2.33 & 1.95 & 0.00 & 0.73 & 0.16 & 0.52 \\
Churachandpur & 4 & 2.66 & 2.21 & 0.66 & 0.84 & 0.36 & 0.62 \\
Kamjong & 4 & 2.00 & 1.60 & 0.33 & 0.56 & 0.33 & 0.42 \\
Chandel & 4 & 1.66 & 1.22 & 0.00 & 0.24 & 0.16 & 0.13 \\
\hline
\end{tabular}

$n=$ No. of individuals; $\mathrm{Na}=$ No. of alleles; $\mathrm{Ne}=$ Effective No. of alleles; PA = Private Allele $I=$ Shannon's Index; Ho = Observed Heterozygosity; He = Expected

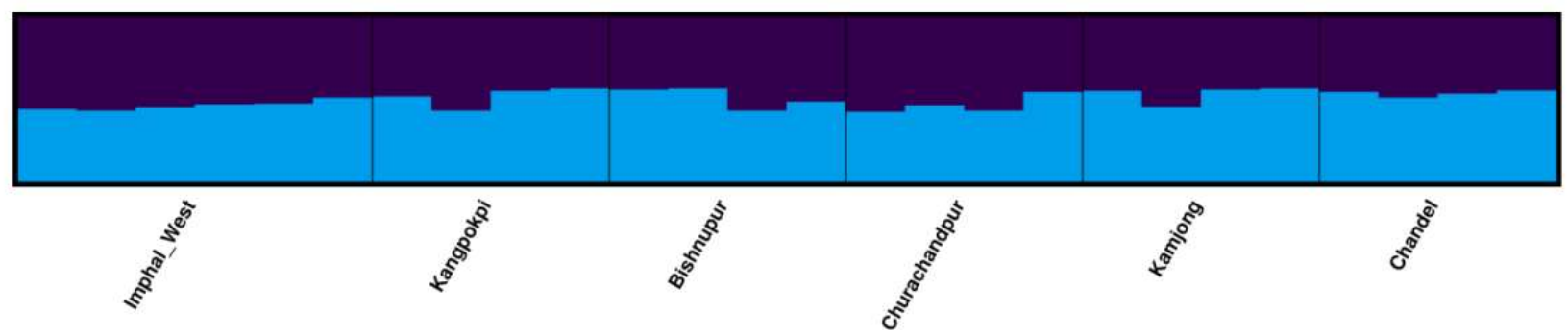

Fig. 1. Genetic structure of Parkia with $K=2$ for 26 farmer-selected tree bean (Parkia timoriana) genotypes from Manipur under Admixture model. Each colour represents possible admixture from different lineage or cluster 
Table 5. Analysis of molecular variance for 6 populations of tree bean (Parkia timoriana) from Manipur

\begin{tabular}{lccccc}
\hline Source of variation & d.f & Sum of squares & Est. variance & Total variance (\%) & P-value \\
\hline Among populations & 5 & 7.27 & 0.12 & 12.50 & $<0.01$ \\
Among Individuals & 20 & 15.62 & 0.42 & 38.00 & $<0.01$ \\
Within Individuals & 26 & 8.00 & 0.42 & 49.50 & $<0.01$ \\
Total & 51 & 30.90 & 0.97 & 100 & \\
\hline
\end{tabular}

d.f. = Degree of freedom; P-value is base

$=2$ was the largest value indicating the selections have originated from two genepools (Fig. 1), but each group a mixture of individuals from different sites. However, there was no clear-cut inclination of selections to any specific genepool, but were all mixture of both. The scatter plot along the two principle components explained $73.42 \%$ of the total variation. Grouping of selected individuals in different axis of the PCA graph was not dictated by geographical origin (Fig. 2). Past records from the print media reveal extensive cultivation of tree beans by farmers and plantations in nonagricultural lands by government and non-government agencies, which lead us to believe that large scale physical movement of propagating material across the state occurred in the past, especially within the valley areas of Manipur.

This study clearly showed that ample genetic variation is represented among the 26 farmer-selected trees from the valley region of Manipur based on only three microsatellite markers. The common perception that informal selection by farmers generally lead to genetic deficiencies in planted populations does not hold true in this case. However, due to less number of markers used we were unable to detect the diversity levels of individuals, hence a need to develop more SSR markers for the species. Extensive cultivation and plantation activities of tree beans in the state has led to routine movement of planting materials across sites eliminating major population differentiation. Tree bean is an IFT that has enormous economic potential for the farmers of the region and the selected population will play a major role in shaping the genetic future of on and off farm plantations. The selected individuals considered in the study though diverse are not sufficient to constitute a genetically sound base population for future breeding programs. Further, we are unaware whether selected individuals produce pods that meet market demand. Towards this end, it is recommended that the number of selections should be increased to meet greater breeding challenges of the future and selection should be based on refined criteria that are more market oriented.

\section{REFERENCES}

Angami T, Rupankar B, Letngam T, Makdoh B, Nirmal Mungmuana Kumar AB, Rajendran S and Muniappan A 2017. Traditional uses, phytochemistry and biological activities of Parkia timoriana (DC.) Merr., an underutilised multipurpose tree bean: A review. Genetic Resources and Crop Evolution 65(2): 679-692.

Anonymous 1981. Vegetables-IBPGR Secretariat Rome, pp 76-77.

Bumrungsri S, Harbit A, Benzie C, Carmouche K, Sridith K and Racey P 2008. The pollination ecology of two species of Parkia (Mimosaceae) in southern Thailand. Journal of Tropical Ecology 24(5): 467-475.

Dent EA and VonHoldt BM 2012. Structure harvester: a website and program for visualising STRUCTURE output and implementing the Evanno method. Conservation Genet Resources 4(2): 359361.

Doyle JJ and Doyle JL 1987. A rapid DNA isolation procedure for small quantities of fresh leaf tissue. Phytochemical Bulletin 19(1): 11-15.

Evanno G, Regnaut S and Goudet J 2005. Detecting the number of clusters of individuals using the software structure: A simulation study. Molecular Ecology 14(8): 2611-2620.

Glaubitz JC 2004. Convert: A user friendly program to reformat diploid genotypic data for commonly used population genetic software packages. Molecular Ecology Notes 4: 309-310.

Hamrick JL 1979. Genetic variation and longevity, pp. 84-113. In: Solreg $\mathrm{O}$, Jain $\mathrm{S}$, Johnson $\mathrm{G}$ and $\mathrm{P}$ Raven (eds). Topics in plant reproductive biology. Columbia University Press, New York.

Hamrick JL and Godt MJW 1996. Effects of life history traits on genetic diversity in plant species. Transaction of the Royal Society of London Series B 351(1345): 1291-1298.

Hollingsworth P, Dawson I, Goodall-Copestake W, Richardson J-E, Weber J, Sotelo Montes C and Pennington R 2005. Do farmers reduce genetic diversity when they domesticate tropical trees? A case study from Amazonia. Molecular Ecology 14(2): 497-501.

Ickowitz A, Powell B, Salim MA and Sunderland TCHH 2014. Dietary quality and tree cover in Africa. Glob. Environment Change 24: 287-294.

Johnson R, St. Clair B and Lipow S 2001. Genetic conservation in applied tree breeding programs, pp. 215-230. In: Thielges B and Sastraapradja SD (eds), Proceedings ITTO conference on In situ and Ex situ conservation of commercial tropical trees, 11-13 June 2001, Yogyakarta, Indonesia.

Kelly BA, Hardy OJ and Bouvet JM 2004. Temporal and spatial genetic structure in Vitellaria paradoxa (shea tree) in an agroforestry system in southern Mali. Molecular Ecology 13(5): 1231-1240.

Kopelman NM, Mayzel J, Jakobsson M, Rosenberg NA and Mayrose I 2015. Clumpak: A program for identifying clustering modes and packaging population structure inferences across K. Molecular Ecology Resources 15(5): 1179-1191.

Lassen KM, Kjær ED, Ouédraogo M and Nielsen LR 2014. Microsatellite primers for Parkia biglobosa (Fabaceae: Mimosoideae) reveal that a single plant sires all seeds per pod. Applications in Plant Sciences 2(6): 1400024.

Lee CT, Wickneswari R, Mahani M and Zakri AH 2002. Maintenance of genetic diversity in Parkia speciosa in logged-over forests. Journal of Tropical Forest Science 14: 163-178

Lengkeek A, Muchugi A, Agufa C, Ahenda J and Dawson I 2006. Comparing genetic diversity in agroforestry systems with natural forest: A case study of the important timber tree Vitex fischeri in 
central Kenya. Agroforestry Systems 67(3): 293-300.

Longvah T and Deosthale YG 1998. Nutrient composition and food potential of Parkia roxburghii, a less known tree legume from northeast India. Food Chemistry 62(4): 477-481.

Loveless MD and Hamrick JL 1984. Ecological determinants of genetic structure in plant populations. Annual Review of Ecology and Systematics 15(1): 65-95.

Luettmann K, Michalczyk IM, Mengel C, Ziegenhagen B, Heymann EW, Pinedo Saboya PP and Bialozyt R 2010. Characterisation of nuclear microsatellite loci in the Neotropical tree Parkia panurensis (Fabaceae). American Journal of Botany 97(5): 34-36.

Mabhaudhi T, Chimonuo VGP and Modi AT 2017. Status of underutilised crops in South Africa: Opportunities of developing reseach capacity. Sustainability 9(9): 1569.

Meitei WI and Singh Al 1990. Organoleptic test of tree bean Parkia roxburghii G. Don. Indian Journal of Hill Farming 3(1): 47-49.

Meirmans PG 2020. Genodive version 3.0: Easy to use software for the analysis of genetic data of diploids and polyploids. Molecular Ecology Resources 20(4): 1126-1131.

Mithofer D 2005. Economics of indigenous fruit tree crops in Zimbabwe Ph.D. dissertation, Hanover University, Germany

Nevo E, Beiles A and Ben-Shlomo R 1984. The evolutionary significance of genetic diversity: Eco- logical, demographic, and life-history correlates, pp. 13-213. In: Mani G S (ed). Evolutionary dynamics of genetic diversity. Springer-Verlag, Berlin, Germany.

Peakall R and Smouse PE 2012. GenAlEx 6.5: Genetic analysis in Excel. Population genetic software for teaching and research-an update. Bioinformatics 28(19): 2537-2539.

Popoola J, Agbolade J, Ajiboye A, Akinola O, Lewu F, Kioko J and Omonhinmin C 2020. Assessment of genetic diversity of African locust bean (Parkia biglobosa Jacq.) landraces using microsatellite markers. Journal of Critical Reviews 7(11): 31963205.

Powell W, Morgante M, Andre C, Hanafey M, Vogel J, Tingey S and Rafalski A 1996. The comparison of RFLP, RAPD, AFLP and SSR (microsatellite) markers for germplasm analysis. Molecular
Breeding 2(3): 225-238.

Pritchard JK, Stephens M and Donnelly P 2000. Inference of population structure using multi locus genotype data. Genetics 155(2): 945-959.

Reed J, Van Vianen J, Foli S, Clendenning J, Yang K, Macdonald M, Petrokovsky G, Padoch C and Sunderland T 2017. Trees for life: the ecosystem service contribution of trees to food production and livelihoods in the tropics. Forest Policy and Economics 84(2): 62-71.

Roy SS, Kumar S, Sharma SK, Devi AR, Singh NA and Ngachan SV 2016. Tree bean (Parkia roxburghii): A potential multipurpose tree legume of Northeast India. Paper presented at National Symposium on Vegetable Legumes for Soil and Human Healthy; February12-14, 2016; Indian Institute of Vegetable Research, Varanasi, India

Salam JS, Singh PK, Dutta BK and Sahoo UK 2009. Chemical composition and nutritive indices in Parkia roxburghii G. Don, a leguminous plant of India. Indian Journal of Agricultural Biochemistry 22(2): 87-93.

Sankanur M, Singh NB, Thakur S, Saresh NV and Verma A 2017. Application of RAPD and ISSR markers for fingerprinting of promising myrobalan Accessions (Terminalia chebula Retz.): An indigenous minor agroforestry tree species. Indian Journal of Ecology 44(4): 13-20.

Start AN and Marshall AG 1976. Nectarivorous bats as pollinators of trees in West Malaysia, pp. 141-150. In: Burley J and Styles BT (eds). Tropical trees: Variation, breeding and conservation in tropical forest trees. Academic Press, London.

Thangjam R 2014. Inter-simple sequence repeat (ISSR) marker analysis in Parkia timoriana (DC.) Merr. populations from Northeast India. Applied Biochemistry and Biotechnology 172(4): 1727-1734.

Vira B, Wildburger C and Mansourian S 2015. Forests and food: Addressing Hunger and Nutrition Across Sustainable Landscapes. Cambridge: Open Book Publishers.

Yeh FC and Boyle TJB 1997. Population genetic analysis of codominant and dominant markers and quantitative traits. Belgian Journal of Botany 129: 157. 